\title{
Bank specific and economic factors on banks non-interest-based activities in Asia Pacific region
}

\begin{abstract}
This study investigates bank specific and economic factors on bank non-interest based activities in Asia Pacific region banking sector over the years 2000-2015. We employ pooled OLS and panel regression to assess the bank specific and economic factors effect on bank non-interest based activities throughout 61 representative banks across Australia, Hong Kong, Korea, Malaysia, Singapore and Thailand in Asia Pacific region. The empirical findings indicate that the bank specific and economic factors do have impact on banks' non-interest based activities in overall countries, developing and developed countries respectively. We also find that bank non-interest based activities also affected by subprime crisis for developed and developing countries. The findings from this study are expected to contribute significantly toward decision-making for regulators, policymakers, bank managers, investors and also to the existing knowledge on performance of the Asia Pacific banking sector.
\end{abstract}

Keyword: Bank's non-interest activities; Asia-Pacific banking; Bank specific and economic 